\title{
Examining Challenges Facing SMEs Businesses in Dar Es Salaam Tanzania: A Case Study of Ilala and Kinondoni Municipalities.
}

\author{
Lizzy Jimmy Madatta and Qian Chen \\ School of Economics and Management, Zhejiang University of Science and Technology; Hangzhou, CN \\ lizmadatta@gmail.com
}

\begin{abstract}
The analysis of different SMEs definitions worldwide reveal that it is very difficult to arrive at a common definition. In fact one study by Auciello (1975) in 75 countries found more than 75 definitions were used in the target countries. This demonstrates very well that there is no common accepted definition of SMEs. SMEs businesses range from very small micro-firms run by one or two persons and very slow growth or no growth to fast growing medium businesses earning millions of dollars and majority employing as many as 250 employees (Fjose et al., 2010). SMEs all over the world and in Tanzania in particular, can be easily established since their requirements in terms of capital; technology, management and even utilities are not as demanding as it is the case for large enterprises. They are regarded as backbone of economic growth in almost all developed and developing countries. In Tanzania, SMEs contribute over $30 \%$ of the GDP, and employs 3-4 million people, which is $20-30 \%$ of the total labour force (Kazungu, Ndiege and Matolo, 2013). Therefore this paper has identified several challenges facing SMEs such as financial access which is consistently reported as one of the major obstacles to SME's growth and development where only $20 \%$ of African SMEs have a line of credit from a financial institution. And suggests technical approaches to solving them in respect to the developing economy of Tanzania.
\end{abstract}

Keywords: Small and Medium Enterprises (SMEs), Gross Domestic Product (GDP), Challenges.

DOI: $10.7176 / \mathrm{JESD} / 11-17-07$

Publication date:September $30^{\text {th }} 2020$

\section{Introduction}

Due to fierce competition in the domestic market, many of Chinese SMEs focus on the foreign market, with its unique product and price advantage, they gradually moving towards the international market, and have made a great contribution on activating China's economy, improving competitiveness of our products in the international market, and promoting economic international exchange of technology; now they has been an important force in China's foreign exports.

Financing problem faced by SMEs financial system are not perfect and their financial management are confusing, lacking of dedicated professional accountants, their financial transparency of the information provided by the finance department reports is low and there is a serious beautification report fraud, which are difficult for banks and other financial institutions to give them a fair and reasonable corporate credit rating, so it is difficult to decide whether the bank approved the loan business. Serious information asymmetry between SMEs and banks leads to the low financing efficiency. The credit line of SMEs are generally not high, and they seldom have sense of credit, leading banks and other financial institutions invest are very cautious when investing for SMEs

\subsection{Statement of Problem}

More than $95 \%$ of businesses in Tanzania are small enterprises. Together, they contribute about $35 \%$ of the country Gross domestic Product (GDP). There are currently in excess of a million entrepreneurs in Tanzania running Small, Medium or Micro Enterprises (SMME's) responsible for generating up to $40 \%$ of total employment. Although SME's are found in all sectors of the economy; they are dominant in trade (54\%) followed by services (34\%). Micro and small enterprises are critical for supporting livelihoods as well as overall prosperity and progress. They create employment at relatively low levels of investment per job; utilize and add value to local resources; foster equitable income distribution; and are better positioned to meet local needs in small markets. The technologies used by them are easier to acquire, transfer and adopt even for people with little education and training. They have the potential to compliment large enterprises through partnerships and subcontracting relationships. Micro and small enterprises also serve as training ground for entrepreneurship managerial development (Olomi, 2006).

(Naruanard Sarapaivanich 2006) asserts that SMEs are increasingly playing an important role in the economy of many countries. Thus, governments throughout the world focus on development of the SME sector to promote 
economic growth. The Tanzanian government has to recognize the crucial role of SMEs in economic development, employment, and income generation.In spite of constraints faced by SMEs, government spearheading programs that cover Rural development strategy, Agricultural sector development strategy, Strategic trade policy, Business environment strengthening for Tanzania programme (BEST), Micro finance policy and poverty alleviation strategy which aimed to support the SMEs development. In addition, the government has convened the national SMEs steering committee (under Ministry of Industry), whose main focus is to coordinate all SME activities in the country (ibid, 2006).A host of problems makes it difficult for SME's to exploit the existing potentials for further employment and wealth creation. One of the most serious impediments is limited capacity of people who start and operate the businesses, in terms of the attitudes, motivation, exposure, skills and experiences. This capacity limitation is exacerbated by the effects of other problems including a cumbersome regulatory framework, limited access to finance and working premises. Thus this paper reason out that "Critical policy issues" will benefit the current and future government and policy makers in understanding the challenges and needed solution for SMEs to solve socioeconomic issues. To other sectors of the economy, a better understanding of SMEs and financial credit operations provide a chance for stakeholders and other sectors to utilize resources more rationally through linking the sectors of the economy.

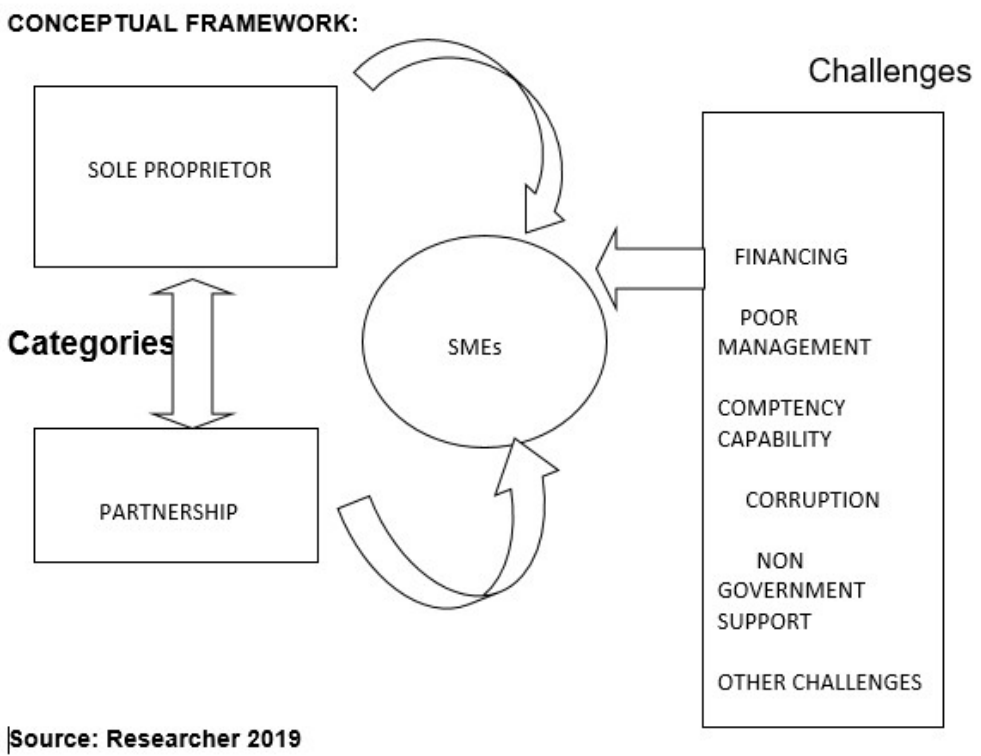

Figure 1: Conceptual Framework

\subsection{Literature Review 2.1 INTRODUCTION}

The chapter reviews various theoretical and empirical literatures and defines key terms used in the study. This chapter reviews the existing literature on the SMEs sector from different countries and in Tanzania. SMEs definitions, challenges, importance, policy and other relevant aspects to this study are also highlighted.

\subsection{Theoretical View on SME}

After the reform and opening-up policy in 1978, dual-track approach was adopted by the Chinese government to develop the market economy. Large state-owned enterprises are protected while private-owned enterprises are encouraged to flourish. On the other hand, large amount of foreign direct investment has also provided capital and managerial knowledge to local enterprises. Thus, SMEs, which used to be called as township and village enterprises, began to flourish. In later years, SMEs have made significant contributions to China's economy and society, because they are providing a large number of job opportunities which become the main destination for workers laid-off from state-owned enterprises (SOEs) that re-enter the workforce (American Embassy in China, 2002). The Small and Medium-sized Enterprise (SME) sector performs a significant roles worldwide (Abor et al., 2008). 
SMEs have a potential contribution socially and economically by contributing noticeably in job creation, revenue creation, innovations, as well as a catalyst for urban and rural area's growth (Hallberg, 2000; OECD, 2004; Williams, 2006; Fatoki \& Asah, 2011). Most of the industrialized countries, over $98 \%$ of all manufacturing sector firms originate from the SMEs sector and they are main employment providers (Sanusi, 2003). The SME sector employs more than $22 \%$ of the productive labor force in the developing countries (Kayanula et al., 2000). According to Singh et al., (2010), SMEs contribute substantially in the manufactured exports of East Asia (56 per cent in Taiwan, over 40 per cent in China and the Republic of Korea, and 31 per cent in India) (Kirumba, 1995). SMEs all over the world and in Tanzania in particular, can be easily established since their requirements in terms of capital; technology, management and even utilities are not as demanding as it is the case for large enterprises. They are regarded as backbone of economic growth in almost all developed and developing countries, SMEs contribute about 50 per cent to the UK GDP and close to 70 per cent of employment opportunities (Pressey et al., 2009). According to Singh et al., (2010), SMEs contribute substantially in the manufactured exports of East Asia (56 per cent in Taiwan, over 40 per cent in China and the Republic of Korea, and 31 per cent in India) (Kirumba, 1995). Despite all these contributions to socio-economic development, SMEs in Tanzania are characterized by constraints such as very low productivity, poor infrastructure, inadequate power supply, low capital, poor market access, and high prices of inputs (Kazungu, Ndiege, Mchopa, and Moshi, 2014), unfavorable legal and regulatory framework, undeveloped, limited access of SMEs to finance, ineffective and poorly coordinated institutional support framework and others (Ngasongwa, 2002). Another critical problem to the performance of SMEs according to Obanda (2012) and Olomi (2005) is access to means of exploiting public procurement opportunities as a means to empower them, with no incentives, guideline and laws that are guiding all Government This gives a proof of substantial obstacle that operators of SMEs are facing in winning public procurement units to first purchase commodity or service from SMEs (Qin and Xiaoyun, 2008), procurement opportunities. Despite all these contributions to socio-economic development, SMEs in Tanzania are characterized by constraints such as very low productivity, poor infrastructure, inadequate power supply, low capital, poor market access, and high prices of inputs (Kazungu, Ndiege, Mchopa, and Moshi, 2014), unfavorable legal and regulatory framework, undeveloped, limited access of SMEs to finance, ineffective and poorly coordinated institutional support framework and others (Ngasongwa, 2002). Another critical problem to the performance of SMEs according to Obanda (2012) and Olomi (2005) is access to means of exploiting public procurement opportunities as a means to empower them, with no incentives, guideline and laws that are guiding all Government procurement units to first purchase commodity or service from SMEs (Qin and Xiaoyun, 2008). This gives a proof of substantial obstacle that operators of SMEs are facing in winning public procurement opportunities. The contribution of Small and Medium-sized Enterprise (SME) sector in economic development, job creation and income generation has been recognized worldwide.

\subsection{Methodology}

\subsection{Research Design}

Research design is the base which proceeds towards the study of the problem after formulating our research problem. A research design can therefore be said to be an arrangement of conditions for collection and analysis of data in a manner that aims to combine relevance to the research purpose with economy in procedure. This chapter is about research strategies, survey population area of research sampling design and procedures. This chapter presents the methods of data collection, data processing and the analysis of the data using SPSS, which comprises remarkable capabilities and flexibilities in analyzing huge data within a short time. Both primary and secondary data were used for this study. Primary data was collected through questionnaires. Part one consisted of demographic information and part two on the challenges faced by SME owners regarding the policy and administrative challenges, financial challenges, technical challenges, marketing issues challenges and education and training challenges. The techniques used are descriptive statistics.

\subsection{Study Area}

The study was conducted within Kinondoni and Ilala municipalities. Administratively, Ilala municipality is divided into 3 divisions, 22 wards, 65 sub-wards, 9 villages, and 37 hamlets. The wards include: Ukonga, Pugu, Msongola,Tabata, Kinyerezi, Ilala, Mchikichini, Vingunguti, Kipawa, Buguruni, Kariakoo, Jangwani, Gerezani, Kisutu, Mchafukoge, Upanga Mashariki, Upanga Magharibi, Kivukoni, Kiwalani, Segerea, Kitunda and Chanika. It has a total population of 1,220,611 the municipal area is about 210 Square $\mathrm{Km}^{2}$. The Borders include Indian Ocean to the East, the Coastal Region to the West, Kinondoni municipality to the North. Knondoni District is in North West of Dar es Salaam central business district Tanzania, others being Temeke (to the far Southeast) and Ilala (downtown Dar es Salaam). To the east is the Indian Ocean, to the north and west the Pwani Region of 
Tanzania. The area of Kinondoni $531 \mathrm{~km}^{2}$. Administratively, Kinondoni District is broken into four divisions, 27 wards, 113 sub-wards. Wards include Bunju, Goba, Hananasif, Kawe, Kibamba, Kigogo, Kijitonyama, Kimara, Kinondoni, Kunduchi, Mabibo, Magomeni, Makuburi, Makurumula, Manzese, Mbezi, Mburahati, Mbweni, Mikocheni,Msasani, Mwananyamala, Mzimuni, Ndugumbi, Sinza,Tandale and Ubungo. Total population of $1,775,049$.

\subsection{Study Type}

This was a cross sectional study design among SME's in Kinondoni and Ilala municipalities of Dar es Salaam in Tanzania. The design allowed direct collection of quantitative data on challenges facing different categories of SME's in the study areas. This was sufficient to address the intended research questions.

\subsubsection{Research Design}

According to Silverman (1993:2) methodology is a general approach to studying a research topic. It establishes how one will go about studying the phenomenon. The chosen methodology guides the techniques for the data gathering and data analysis. Positivism, which seeks to discover laws by quantitative methods, is an example of a methodology. Methods are the specific research techniques. These include quantitative techniques like statistical correlations as well as qualitative techniques like observations and interviewing (Silverman 1993: 2).The study was descriptive and comparative in nature. The source for the study comprised books academic journals, newspapers the internet, official and unofficial documents. Questionnaires formed the major part of understanding and giving the answers to the study of the challenges hindering SMEs businesses

\section{Key Variables Data}

\section{Dependent Variable \\ Independent variables \\ Ownership of SME's \\ Type of SME \\ Location}

\author{
Categories of different SME's \\ sole proprietor or partnership, gender \\ Services, Production, Marketing \\ Urban or Peri-urban.
}

A structured questionnaire was developed in English and translated in to Swahili, the language spoken by all Tanzanian. A back translation was done to check for validity. The questionnaire collected information on different categories of SME's, Ownership, Type, and location of SME. After acquiring permission from the authorities, a structure questionnaire were administered among selected study population elements.

The investigator worked with research assistants to address the question which occurred.

\subsection{Research Instruments}

\subsubsection{Questionnaires}

The study gathered data through the use of a structured questionnaire to collect data from SMEs. A questionnaire is a list of questions, which seeks to source data from the people to answer certain laid down research (Veal, 2005). According to Crowther \& Lancaster (2009), questionnaires for quantitative research in the social sciences are usually designed with the intention of being operational definitions of concepts, instruments that reflect strength of attitudes, perceptions, views and opinions. Questions were simple, direct and appropriate in relation to the target population.

\subsubsection{Survey Population}

The owner/s of the SME, Managers and staff. Samples of 70 SME's were randomly selected 35 from each municipality to include the four types service, production, marketing and tourism of which owners , managers and employees were involved to make a total of 300 sample size. 


\subsubsection{Multi stage Random sampling}

A sampling frame of all SME's in Ilala municipal and Kinondoni was obtained and grouped based on type and category of SME. The stratification followed random selection of the SME using lottery method (simple random sampling). A total of 70 SME's were selected, 35 from each municipality. Random sample of the staff to make a total of 140 two from each SME were obtained and a total of 70 managers from each SME involved aimed at 300 as sample size. However response was $95 \%$ which is total of 285 .

\subsubsection{Data Processing and Analysis}

Secondary data included the financial statements, annual reports, articles written about the SME's, and the key figures. Data was collected, analyzed and presented using both qualitative and quantitative methods.

\subsection{Data Analysis}

The section presents and analyses the data, the information collected from respondents are discussed and reported in this chapter. The target population for this research includes all small businesses in Kinondoni and Ilala Municipalities. The study comprised both qualitative and quantitative approaches for analyzing and presenting the findings, this simplified the discussion and presentation of the information by using SPSS 21 (Statistical Package for Social Sciences). The researcher provided a total of 300 questionnaires to SME's distributed equally among the Municipals based on the research objectives, $140(93.33 \%)$ of the 150 of distributed questionnaires provided to Ilala Municipal were collected and 144 (96\%) out of 150 questionnaires responded from Kinondoni Municipal accordingly. The study based on experience in running the business and actual condition of the business, difficulty opinion with regulatory Authorities, grading the quality of services offered to SME's by Institutions and evaluation and problems impact to business success.

\subsection{Analytical Discussion}

Table 4.1: Comparative analysis of constraints SME's running the business, grading difficulties on regulations, grading quality of service offered by institutions and evaluation problems impacts.

\begin{tabular}{|c|c|c|c|c|}
\hline \multirow[b]{2}{*}{ Variable } & \multicolumn{2}{|l|}{$\begin{array}{l}\text { Ilala } \\
\text { Municipal }\end{array}$} & \multicolumn{2}{|l|}{$\begin{array}{l}\text { Kinondoni } \\
\text { Municipal }\end{array}$} \\
\hline & Frequency & $\begin{array}{l}\text { Percentage } \\
\%\end{array}$ & Frequency & $\begin{array}{l}\text { Percentage } \\
\%\end{array}$ \\
\hline $\begin{array}{l}\text { Lack access to facts of } \\
\text { technologies }\end{array}$ & 84 & 60 & 99 & 68.8 \\
\hline $\begin{array}{ll}\text { Lack of government } \\
\text { assistance }\end{array}$ & 46 & 32.9 & 21 & 14.6 \\
\hline Capital constraints & 35 & 25 & 37 & 25.7 \\
\hline Lack of access to customers & 15 & 10.7 & 27 & 18.8 \\
\hline $\begin{array}{l}\text { Lack of access to records on } \\
\text { authorities policies }\end{array}$ & 104 & 74.3 & 93 & 64.6 \\
\hline Lack of new technology & 101 & 72.1 & 111 & 77.1 \\
\hline $\begin{array}{l}\text { Limited access to statistics on } \\
\text { marketplace }\end{array}$ & 111 & 79.3 & 13 & 9 \\
\hline Limited access to providers & 140 & $100^{2}$ & 25 & 17.4 \\
\hline $\begin{array}{l}\text { Limited access to facts on } \\
\text { finance }\end{array}$ & 98 & 70 & 65 & 45.1 \\
\hline $\begin{array}{l}\text { Lack of expert association and } \\
\text { affiliation }\end{array}$ & 91 & 65 & 71 & 49.3 \\
\hline Lack of Government packages & 62 & 44.3 & 102 & 70.8 \\
\hline Lack of credit score from banks & 90 & 64.3 & 85 & 59 \\
\hline $\begin{array}{l}\text { Limited support to commercial } \\
\text { enterprise }\end{array}$ & 101 & 72.1 & 109 & 75.7 \\
\hline
\end{tabular}




\begin{tabular}{|l|l|l|l|l|}
\hline $\begin{array}{l}\text { Difficulty firm registration } \\
\text { regulations }\end{array}$ & 95 & 67.9 & 67 & 46.5 \\
\hline $\begin{array}{l}\text { Difficulty license for begin of } \\
\text { business regulations }\end{array}$ & 17 & 12.1 & 17 & 11.8 \\
\hline $\begin{array}{l}\text { Difficulty customs policies } \\
\text { regulations }\end{array}$ & 12 & 8.6 & 27 & 18.8 \\
\hline $\begin{array}{l}\text { Difficulty employment } \\
\text { regulations }\end{array}$ & 22 & 15.7 & 12 & 8.3 \\
\hline $\begin{array}{l}\text { Dificulty health and protection } \\
\text { policies }\end{array}$ & 22 & 15.7 & 47 & 32.6 \\
\hline Difficulty tax rules regulations & 35 & 25 & 59 & 41 \\
\hline $\begin{array}{l}\text { Difficulty environmental } \\
\text { guidelines } 11\end{array}$ & 7.9 & 22 & 15.3 \\
\hline Lack of market knowledge & 16 & 11.4 & 31 & 21.5 \\
\hline $\begin{array}{l}\text { Lack of statistics on market } \\
\text { possibilities }\end{array}$ & 22 & 15.7 & 108 & 75 \\
\hline $\begin{array}{l}\text { Competition in domestic } \\
\text { market }\end{array}$ & 39 & 27.9 & 40 & 27.8 \\
\hline $\begin{array}{l}\text { Competition in overseas } \\
\text { market }\end{array}$ & 95 & 63.9 & 85 & 59.1 \\
\hline $\begin{array}{l}\text { High interest prices on bank } \\
\text { loans }\end{array}$ & 115 & 82.1 & 95 & 66 \\
\hline $\begin{array}{l}\text { Ensuring guarantees for bank } \\
\text { loans }\end{array}$ & 21 & 15 & 35 & 24.3 \\
\hline $\begin{array}{l}\text { Long mortgage utility } \\
\text { processing }\end{array}$ & 36 & 25.7 & 56 & 38.9 \\
\hline $\begin{array}{l}\text { Imperfect competition "black } \\
\text { marketplace }\end{array}$ & 67 & 47.9 & 95 & 66 \\
\hline The smuggling of foreign items & 113 & 80.7 & 117 & 81.3 \\
\hline $\begin{array}{l}\text { Police quality of service } \\
\text { offered }\end{array}$ & - & - & 61 & 42.4 \\
\hline $\begin{array}{l}\text { Chamber of commerce quality } \\
\text { of service offered }\end{array}$ & 57 & 40.7 & 102 & 70.8 \\
\hline $\begin{array}{l}\text { Court of businesses quality of } \\
\text { service offered }\end{array}$ & 95 & 67.9 & 104 & 72.2 \\
\hline $\begin{array}{l}\text { Electricity provider } \\
\text { TANESCO quality of service } \\
\text { offered }\end{array}$ & 109 & 77.9 & 75 & 52.1 \\
\hline $\begin{array}{l}\text { Water provider - DAWASCO } \\
\text { quality of service offered }\end{array}$ & 116 & 82.9 & 118 & 81.9 \\
\hline $\begin{array}{l}\text { Telecommunication services } \\
\text { vendors quality of service } \\
\text { offered }\end{array}$ & 112 & 80 & 118 & 81.9 \\
\hline Source: Researcher, 2020 & 104 & \\
\hline
\end{tabular}

\subsubsection{Access to facts of Technologies to Business}

Technological progress is one of the theoretically accepted measures applied to eliminate the frontier barrier of an economy because it helps to increase the productivity and efficiency of factors of production of the economylabor, capital, and other resources, and increase the production input usage in the production. According to Schumpeter, innovation needs entrepreneurial skills to manage existing or new resources to match with new 
scientific discoveries in the production process and organize the output.

\subsubsection{ICT Transfer: Findings and Discussion}

It is no secret that small and medium business enterprises play a major role in spurring economic development. Governments everywhere have begun to ask themselves what they can do to encourage the growth of SMEs, thus enabling them to contribute to the national economy.

\subsubsection{Government assistance to business}

It is no secret that small and medium business enterprises play a major role in spurring economic development. Governments everywhere have begun to ask themselves what they can do to encourage the growth of SMEs, thus enabling them to contribute to the national economy.

\subsubsection{Capital Constraints}

Access to finance is often cited as an important factor in the survival and growth of small businesses. Financial constraints affect SME growth and survival through two channels during economic instability. Unlike large companies, which are better placed to absorb cyclical fluctuations in demand, small businesses are more vulnerable to swings in revenue growth. This is especially true during economic downturns when business revenue decreases and the demand for external finance increases.

\subsubsection{Access to Customers}

All businesses compete with other companies to attract customers, either by aggressively advertising their products, by lowering prices to expand their customer bases or developing unique products and experiences that customers love In some cases, SMEs struggle to ensure that the right product is available in the right quantities at operational level. Errors and delivery problems can occur and this is not beneficial for any SME's reputation.

\subsubsection{Access to records on Authorities Policies}

Tanzania has recognized the impact of proper records management on the efficiency of government operations and on accountability and transparency in the public sector and has been working to strengthen its records management systems (International Records Management Trust, 2011).

\subsubsection{New Technology}

Companies always seek to get competitive advantages and one of the most researched is innovation. The innovation concept is not totally clear, and there are many different perspectives on innovation in the current research. For SMEs innovation is as important as for large companies and many innovations emanate from SMEs.

\subsubsection{Access to Statistics on Marketplace}

Whether you already have your own business, or are planning to start a new one this year, these statistics will help you make sense of what's new and what you should expect. These statistics will help you understand what influences small business, how they work, and how they impact the economy and many more details. In the past few years, SMEs have continued to generate employment. SMEs are also key players in contributing to innovation.

\subsubsection{Limited Access to Providers and Access to facts on Finance}

An access provider is any organization that arranges for an individual or an organization to have access to the Internet. Access providers are generally divided into two classes: Internet access providers (ISPs) and online service providers (OSPs).

Access to Finance Generally lack of short, medium and long term capital, inadequate access to financial resources and credit facilities affect the growth of micro and small scale enterprises (MSEs). In fact the cost of capital is 
higher for the small scale manufacturer, the effect is even compounded by raising inflation rate (Osotimehin, K.O, 2012)

\subsubsection{Expert Association and Affiliation}

An affiliate or associate business is a company with a parent corporation that owns less than a controlling percentage of the company's voting stock.

\subsubsection{Credit score from banks}

Credit scoring is an automated statistical method used to assess the risk of default of a credit applicant. It involves analyzing large amounts of historical data on borrowers to identifying certain characteristics that predict the likelihood of the borrower defaulting on his/her loan sometime in the future. These data could include, for example, the economic sector, years in business and size of assets. Using the results from this analysis, the bank can design a scorecard for evaluating the risk associated with each credit application.

\subsubsection{Support to Commercial Enterprise}

The organized action of making of goods and services for sale, field of operation, line of business, a particular kind of commercial enterprise, employee-owned business, employee-owned enterprise a commercial enterprise owned by the people who work for it

\subsubsection{Firm Registration Regulations}

Starting a corporation requires a person to apply for the Certificate of incorporation from Business Registration and Licensing Authority (BRELA). The promoters of the company are required to draw and submit the certificate and Memorandum and articles of association

\subsubsection{License for Begin of Business Regulations - (BRELA)}

The Business Registrations and Licensing Agency (BRELA) is an Executive Agency under the Ministry of Industry and Trade responsible for business administration and regulation of the laws; namely Companies Registration, Business Names Registration, Trade and Service Marks Registration, granting of Patents and issuing of Industrial License. It was established under the Government Executive Agencies Act No. 30 of 1997 and formally launched on 3rd December 1999.

\subsubsection{Customs Policies Regulations}

The customs department and the port authorities are the greatest hindrance to importers throughout Tanzania. Clearance delays and extra-legal levies are commonplace when dealing with customs officials within the Tanzania Revenue Authority (TRA). These hindrances can cause unpredictable delays when importing goods into the country. However there are some benefits for large taxpayers who have a track record of compliance, including expedited clearance and reduced auditing.

\subsubsection{Employment Regulations}

The Tanzania labor law protects all professionals and non-professionals engaged in an employment (with employer-employee relationships), with or without employment contracts. This excludes employees working under the public sector who are covered under the Public Service Act.

\subsubsection{Difficulty Health and Protection Policies}

Occupational health and safety is related with economic activities undertaken in the country. As the economic activities grow and expand, occupational injuries and diseases are more likely to increase among workers in different sectors of economy such as agriculture, mining, transport, and manufacture. This may result in high occupational health and safety services demand, which might be difficult to meet by developing countries that are prioritizing economic expansion without regard to their impact on occupational health and safety.

\subsubsection{Tax Rules Regulations}

The Tanzania Revenue Authority (TRA) was established by Act of Parliament No. 11 of 1995, and started its operations on 1st July 1996. In carrying out its statutory functions, TRA is regulated by law, and is responsible for administering impartially various taxes of the Central Government.

\subsubsection{Environmental Guidelines}

The complexity of environmental problems means that many sectors of the government and society are involved in actions to address them. In Tanzania, the Office of the Vice President is responsible for the Environment. This Office, using the Division of Environment, is responsible for the development of policy options, and coordination 
of the broad-based environmental programs and projects. It is also responsible for facilitating meaningful involvement of civil society in environmental activities.

\subsubsection{Market Knowledge}

Market knowledge is to know about the various aspects associated with the business one is offering to the market. It includes detail study about the primary and secondary activities that a company can include in its core activities so that value can be delivered to the market.

\subsubsection{Statistics on Market Possibilities}

Statistics are applied in marketing to identify market trends, and to measure and evaluate the potential and success of marketing programs. The secret to successful marketing is to identify the target market accurately and to use effective marketing communications channels and tactics to reach it. Statistics can help the marketer achieve both of those goals as well as evaluate the success of the marketing effort and provide data on which to base changes to the marketing program.

\subsubsection{Competition in Domestic Market}

The competition level in the domestic market is important not only for consumers, who enjoy lower prices and higher variety. Higher competition in the domestic market also shifts necessary resources from less productive domestic-oriented firms to export-oriented productivity champions

\subsubsection{Competition in Overseas Market}

Global marketing is defined as the process of adjusting the marketing strategies of your company to adapt to the conditions of other countries. Of course, global marketing is more than selling your product or service globally. It is the full process of planning, creating, positioning, and promoting your products in a global market.

\subsubsection{High Interest Prices On Bank Loans}

High-interest rates make loans more expensive. When interest rates are high, fewer people and businesses can afford to borrow. That lowers the amount of credit available to fund purchases, slowing consumer demand. At the same time, it encourages more people to save because they receive more on their savings rate. Owners of SMEs, however, perceive these formal loans to be high risk due to the high-interest rates, strict loan conditions and numerous collaterals placed on these loans.

\subsubsection{Ensuring Guarantees for Bank Loans}

The bank guarantee means that the lender will ensure that the liabilities of a debtor will be met. In other words, if the debtor fails to settle a debt, the bank will cover it. A bank guarantee enables the customer, or debtor, to acquire goods, buy equipment or draw down a loan.

\subsubsection{Imperfect Competition "Black Marketplace"}

A black market, underground economy or shadow economy, is a clandestine market or series of transactions that has some aspect of illegality or is characterized by some form of noncompliant behavior with an institutional set of rules. If the rule defines the set of goods and services whose production and distribution is prohibited by law, non-compliance with the rule constitutes a black market trade since the transaction itself is illegal.

\subsubsection{8 the Smuggling of Foreign Items}

Smuggling refers to covert movement of goods into or out of the country in order to evade taxes or limitations on imports or exports, and involves practical difficulties relating to clandestine activity and risks of detection by customs and excise.

\subsubsection{Police Quality of Service Offered}

The Tanzania Police Force is a national police force. The functions of the Police Force are stated thus in the Police Force Ordinance.

\subsubsection{Chamber Of Commerce Quality of Service Offered}

The Tanzania Chamber of Commerce, Industry and Agriculture (TCCIA) is a government agency of Tanzania with a mandate to promote business and industry, and to facilitate an interface between the private sector and public sector in the country. TCCIA was founded in 1988 and its head offices are in Dar es Salaam.

4.1.30 Court Of Businesses Quality of Service Offered

The Investment Policy Review considered the Tanzanian National Business Council (TNBC) and the National 
Investment Steering Committee (NISC) to be vital to the improvement of the investment climate. Where the TNBC was concerned, it recommended continued efforts to remove barriers to efficient business operation, and vigorous follow-up to problems identified subsequently.

\subsubsection{Electricity provider - TANESCO Quality of Service Offered}

Tanzania Electric Supply Company Limited (TANESCO) is a Parastatal organization established by Memorandum and Articles of Association incorporated in 26th November 1931 which established Tanzania Electric Supply Company Limited (the then Tanganyika Electric Supply Company Limited -TANESCO). The Company generates, purchases, transmits, distributes and sells electricity to Tanzania Mainland and sells bulk power to the Zanzibar Electricity Corporation (ZECO), which in turn sells it to the public in islands of Unguja and Pemba. TANESCO owns most of the electricity generating, transmitting and distributing facilities in Tanzania Mainland with estimated population of 50 million.

\subsubsection{Water provider - DAWASCO quality of service offered}

The Dar es Salaam Water Supply and Sewerage Authority is responsible for providing water supply services to its customers (about 100000 ) in its area of operations. DAWASA also provides sewerage services to a small number of customers (around 20 000) in the City of Dar es Salaam. By the late 1990s it was evident that DAWASA was unable to respond quickly enough to meet customer demands for improved levels of service and improve finances to adequately maintain and replace its aging assets.

\subsubsection{Telecommunication Services Vendors' Quality of Service Offered}

To date, there are seven landline and mobile operators in Tanzania: Airtel, Halotel, Smile, Tigo, Tanzania Telecommunication Company Limited (TTCL), Vodacom, and Zantel.

\section{Conclusion}

In conclusion, this study has achieved its research objectives. The hypotheses development, theoretical framework and research design were designed to achieve the research objectives. In this study, there are five determinants that significant to affect the performance of small and medium enterprises (SMEs). Based on the results, the first objective of the study was to identify key challenges facing SME's development and growth in manufacturing, trade, tourism and other services sector. According to the study findings the challenges were lack of market possibilities, competition in overseas market, high interest rates for bank loans, and imperfect competition. The registration of firms is cumbersome, complex tax computations, high and multiple taxes. The second objective was to explain strategies applied by SME's the curb the challenges they face by entrepreneurs weighing the benefit of formalizing their business against costs/ risks of working in informal sector. The third objective was to describe government response to challenges facing SME's whereby they have encouraged the harmonization of the SME's Development policy updating and the formulation of a private sector development policy (under preparation) to avoid confusion and overlaps;

\subsection{Recommendations for Further Research}

Since the study picked a case study of two municipals in urban area, further studies can be conducted in the same study basing in rural area. Moreover, further research could be carried out on the factors that contributing to difficulties in regulatory adherence, quality service offering by Institutions, markets possibilities including competition, financial support from financial institutions with lower interest rates favorable to middle income business, enhancing access to finance assets and problems impacting the success of SMEs in Tanzania.

Continuous learning may also facilitate the acquisition of appropriate resources and strategies to SME's undertakings.

\section{References}

Acs, Z.J. and Audretsch, D.B. (1987), 'Innovation, market structure, and firm size', The Review of Economics and Statistics, 69(4), 567-574. Acs, Z. J., Audretsch, D. B. and Feldman, M.P. (1994), 'R\&D spillovers and recipient firm size', The review of Economics and Statistics, 76(2), 336-340.

Amyx,C.(2005). Small Business challenges- The perception problem: Size Doesn't matter. Washington Business Journal, 5

Ariyo, D. (2008). Small firms are the backbone of the Nigerian economy. African Economic Analysis. Auciello, K. E., (1975). Employment generation through stimulation of small industries, an international 
compilation of small-scale industry definitions. Atlanta: Georgia Institute of Technology

Aylin, A., Garango, P., Cocca, P. \& Bititchi, U. (2013) The development of SME managerial practice for effective performance management. Journal of small business and enterprise development, 20 (1), 2854

Ayyagari, M., Beck, T. \& Demirgüc-kunt, A. (2003). Small and medium enterprises across the globe: A new database. Washington, D.C.: World Rank. Retrieved http://siteresources.worldbank.org/INTFR/Resources/

Beck, T. \& Cull, R. (2014). Small and medium-sized enterprise finance in Africa. African Growth Initiative (working paper 16). Washington DC: Brookings.

Beck, T., Asli, D., Luc, L. \& Vojislav, M. (2006). The determinants of financing obstacles. Journal of International Money and Finance, 25, 932-52.

Bhide, A. (1996). The questions every entrepreneur must answer. Harvard Business Review, 74, 120-130

Berryman, J. E. (1983). Small business failure and bankruptcy: A survey of the literature. International Small Business Journal, 47-59.

Berryman, J. E. (1994). Small business failure and bankruptcy: What progress has been made in a decade? Small Enterprise Research, 2, 5-27.

Bouazza, A. B., Ardjouman, D. \& Abada, O. (2015). Establishing the Factors Affecting the Growth of Small and

Medium-sized Enterprises in Algeria. American International Journal of Social Science, 4 (2), 101-115.

Chu, M., O. Kara \& C. Benzing (2010). An empirical study of Nigerian entrepreneur: Success, motivation, problems and stress. International Journal of Business Research, 16.

Cover, J. (1933). Business and personal failure and re-adjustment in Chicago. Chicago: University of Chicago Press.

Davidsson, P. (1989). Entrepreneurship and after? A study of growth willingness in small firms. Journal of Business Venturing, 4(3), 211-226

Fjose, S., Grunfeld, L. A. \& Green, C. (2010). SMEs and growth in Sub-Sahara Africa: Identifying SME Role and obstacles to SME growth. MENON-Publication, 14, 1-28.

Geeta, B. \& Hong, T. (2003). SME Technical Efficiency and Its Correlates: Cross-National Evidence and Policy Implications. World Bank Institute Working Paper. Retrieved on April 8, 2014 from: Info. worldbank.org/etools/docs/

Kamunge, M. S., Njeru, A. \& Tirimba, O. I. (2014). Factors affecting the performance of small and macro enterprises in Limuru town market of Kiambu County. International Journal of Scientific and Research Publications, 4(12), 1-20.

Muriithi, S. M. (2015). The relationship between leadership and organisational effectiveness. Unpublished Doctoral thesis. Grahamstown: Rhodes University.

Ngasongwa, J. (2002). SME policy-draft 1, NFT, 19.11.00. Tanzania, Dar-e-salaam: Minister for industry and Trade

Small business mortality: Annotated bibliography. Small enterprise series no. 3.

Sule, E.I.K. (1986). Small scale industries in Nigeria: Concepts, appraisal of government policies and Suggested solutions to identified problems. CBN Economic and Financial Review, 24(4), 24. 